\title{
UNA APROXIMACIÓN DESDE LA FILOSOFÍA DE LA IMAGEN A LA INVESTIGACIÓN DE LA ICONOCLASIA
}

\author{
Fernando R. Contreras \\ Universidad de Sevilla \\ fmedina@us.es
}

\begin{abstract}
RESUMEN / ABSTRACT
Este artículo estudia las prácticas visuales destructivas de la iconoclasia. La destrucción es un gesto de emancipación y un acto de inmunización frente a la idolatría religiosa, social y política. La evidencia de la influencia de las imágenes en la creación de falsedades permite considerar la acción iconoclasta como un ejercicio de liberación. Analizamos los fundamentos de la ofensiva contra el poder de las imágenes en el espacio público. La mutilación visual, la negación, la censura, la prohibición serán prácticas comunes en un espacio intermedio (estético-político) en el que se enreda la libertad de pensamiento.

Palabras clave: iconoclasia, idolatría, estética, política, destrucción, filosofía de la imagen, estudios visuales, arte, comunicación.
\end{abstract}

\section{AN APPROACH FROM THE PHILOSOPHY OF THE IMAGE \\ TO THE RESEARCH OF ICONOCLASM}

This article studies the destructive visual practices of iconoclasm. Destruction is a gesture of emancipation and an act of immunization against religious, social and political idolatry. The evidence of the influence of images in the creation of falsehoods allows us to consider the iconoclastic action as an exercise in liberation. We analyze the fundamentals of the offensive against the power of images in public space. Visual mutilation, denial, censorship, and prohibition will be common practices in an intermediate space (aestheticpolitical) in which freedom of thought is entangled.

KEYWords: Iconoclasm, Idolatry, Aesthetics, Politics, Destruction, Philosophy of the Image, Visual Studies, Art, Communication.

\section{Introducción: la primacía del sentido de la vista frente al mundo}

La quema pública de banderas, de libros o de fotografías de figuras políticas
son ejemplos repetidos de la aversión a las imágenes. La iconoclasia no es
un fenómeno localizado en una cultura visual local, pues las muestras de disgusto al
poder de las imágenes se extienden por el mundo. La tecnología de internet ha cruzado
las culturas visuales a través de las redes creando conflictos interculturales con las
imágenes. El sentido de la vista, de sus placeres o de sus horrores no es el mismo en
todos los lugares del mundo. Ya el estudio comparativo que Belting (2012) realiza
entre las dos culturas visuales (Occidente y Oriente) ofrece estas primeras evidencias. 
En 2010, durante las revueltas de la "Primavera Árabe" en Túnez, se difundieron las imágenes simbólicas de un movimiento social que terminaba con el régimen autoritario y corrupto de Ben Alí. Mediante las fotografías o streaming de videos de las manifestaciones, pancartas, cuerpos maquillados o banderas fue creándose una imaginería política. En España, un año después, el movimiento $15 \mathrm{M}$ o el movimiento de los "indignados" utilizó la imagen para crear una identidad estética propia. Para ello, los mismos participantes compartieron en Twitter bajo el hashtag \#15M más de 2199 fotografías y 4077 vídeos (véase en 15Mpedia.org). En estos movimientos sociales, la producción visual no es externa a los propios protagonistas. No son los medios de comunicación los autores exclusivos del conjunto de imágenes que componen este universo visual. Los mismos participantes con sus dispositivos tecnológicos (móviles, tabletas, cámaras de videos) han supuesto una reforma visual. Si el descubrimiento de la perspectiva supuso una revolución en la historia de la mirada, la invención de la autoría compartida en la creación de las nuevas imaginerías digitales ha transformado la historia de la mirada al mundo. No solo comprendemos las culturas a través de lo que hacen con sus imágenes, sino también cómo captan el mundo. Ello nos enseña, entre otras cuestiones, su modo de pensar.

Para abandonar los caminos familiares de la historia del arte en el estudio de la iconoclasia nos centraremos concretamente en la relación compleja de la imagen entre el conocimiento y la concepción del mundo. En este estudio, nos preguntamos cómo todavía al hombre de la posmodernidad le aterroriza el poder que desprenden las imágenes. A nuestro juicio, el dominio de las imágenes toma dos direcciones: 1) cuando se conciben desde la medición de la mirada que construye las imágenes (algo que ya preocupaba al renacentista Albrecht Dürer); y 2) cuando consideramos que el mundo está convertido en imágenes (una perspectiva heideggeriana que han actualizado Lipovetsky y Serroy 2015). Tras estas premisas nos encontramos además con el afán del hombre por mirar, que tiene como última consecuencia el progreso de una tecnología global que acrecienta aún más su poder. No es solo la invención de la fotografía o la cinematografía, es el dominio colonial de las imágenes en las redes sociales por internet. El consumo de imágenes, aunque la iconoclasia o la censura política la hayan erosionado una vez y otra, es una batalla imposible de ganar.

Fue la oposición entre la construcción de la mirada y la función del ojo, como órgano natural, la que cambió la concepción del arte visual. Su rastro puede reconocerse en la división entre la tradición artística occidental y la visión oriental de las imágenes. Entre estas dos tradiciones, Belting distingue una diferencia cuando lo enfocamos desde el aspecto cognitivo de las imágenes. La explicación de Belting sobre los modelos antiguos de pensamiento en la historia de los sentidos nos sirve de punto de apoyo para comprender las controversias de la imagen, y, por ende, el origen de la iconoclasia. Si bien en Oriente Próximo la creación de imágenes fue considerada durante largo tiempo un tabú, los occidentales las asumieron como el camino del conocimiento. La teoría árabe de la visión no trata de imágenes, sino de proyecciones sobre el ojo humano. La mirada no era una actividad, sino por el contrario, el ojo humano era un órgano pasivo que recibía señales que controlaba mediante su medición. El espacio visual se hizo un espacio métrico que se calculaba respecto a dos referencias, el observador y su posición. 
Para los occidentales, las imágenes aportaban conocimiento desde la estimulación visual del mundo sobre el hombre. La actitud activa o pasiva frente a las imágenes ha diferenciado dos culturas de la visualidad. Estas dos tradiciones se han fusionado en los umbrales históricos. El cristianismo primitivo perpetuó su actitud negativa hacia las artes plásticas y las artes imitativas. Sin embargo, los elementos estéticos se revalorizaron en la labor propagandística de la comunidad hebrea frente al Imperio Romano. El arte judaico, como el arte cristiano, amparó la emergencia de una cultura independiente, asumiendo la prohibición veterotestamentaria de las imágenes. La prohibición bíblica de imágenes impedía la adoración de ídolos y la invención de nuevos dioses. Fue a través de la ontología neoplatónica y la noción de la belleza cuando fue aceptada la producción de imágenes por los fundadores de la Iglesia. El neoplatonismo buscó la belleza en una suprarrealidad que acercaba las verdades espirituales al alma de los hombres (Contreras 2017b). La religión quiso proteger el sentido de la vista de los horrores y de los placeres que la mirada era capaz de proporcionar. Belting (2012, p. 31) afirma que "en adelante habría un culto de las imágenes como imágenes para el culto". Es la razón central por la que la Modernidad se interpondrá frente al poder de la religión sobre las imágenes y le concederá una gran importancia en otros ámbitos como es la ciencia o el arte.

Desde que las imágenes se unieron a la mirada, nos reconoce Belting (2012), hubo una oscilación en el poder del Estado y de la Iglesia debido a la fuerza de la mirada personal. Los observadores particulares conciben el mundo como imagen, o bien, crean su imagen propia del mundo (diferente a la imagen institucional del Estado). Las imágenes son concebidas de modo diferente de acuerdo a las dos tradiciones culturales: 1) la perspectiva árabe establecerá un sistema matemático que interpreta la visión dentro de un proceso condicionado por una suma de condiciones ambientales. Es decir, la imagen visual es una imagen mental construida en el cerebro (más allá de la imaginación) que nos permite ver el mundo, pero no es una imagen que se sitúe frente a los ojos; y 2) el planteamiento occidental tiene otro punto de partida: las imágenes son percepciones que activan la mirada. La imagen es una construcción, porque el ser humano ve el mundo en imágenes.

Hasta aquí lo expuesto nos encamina hacia varias consideraciones en nuestro estudio: 1) una tesis de trabajo sobre el status ontológico de la iconoclasia que resuelva la cuestión del modo de existencia en la cultura visual contemporánea (lo haremos a partir de una breve aproximación a la naturaleza del icono); 2) adoptaremos un marco epistémico-teórico pluridisciplinar (los estudios visuales o la ciencia de la imagen) que nos ayude a comprender el fenómeno de la iconoclasia en nuestra cultura visual (Belting 2012; Boehm 2011; Davidson \& Nichols 1989; Freedberg 2017; Gamboni 2014; Matusitz 2015; Michalski 1993; Morgan 2005; Peffer 2009; Spraggon 2003); y 3) finalmente, identificaremos los elementos constitutivos de la guerra de imágenes en la cultura contemporánea, denominada también por otros autores, la posmodernidad. El estudio de la imagen requiere, como enseñaba en su obra Husserl (2011), descubrir el sentido que se bosqueja en cualquier cosa, y cuyo significado se inserta en un contexto intuitivo. Lo que vemos en una imagen puede ser reconocido como la percepción de algo ofrecido, de una cosa. Así, Husserl nos dice que lo que vemos en una mirada puede 
hacer presente otras cosas diferentes. Finalmente, reconocemos que en este trabajo no hemos realizado una investigación histórica secuenciada en una dimensión diacrónica, ni un estudio sociológico sincrónico. Presentamos un análisis con una metodología filosófica de carácter fenoménico en la que pretendemos conseguir comprender la experiencia humana de la iconoclasia: ¿Por qué los humanos destruimos las imágenes? ¿Qué tememos del poder de las imágenes? o, sencillamente, ¿cómo podemos pensar la iconoclasia en el mundo contemporáneo?

\section{Lo icónico en la cultura visual}

Nuestra tesis sobre la permanencia de la iconoclasia en la cultura contemporánea comienza con la observación de Gottfried Boehm sobre el giro icónico: "las imágenes tienen una lógica propia y exclusiva, entendiendo por lógica la producción consistente de sentido a partir de verdaderos medios icónicos" (2011, p. 87). Para Boehm, las imágenes no tienen una lógica predicativa, es decir, no obedecen a proposiciones lingüísticas. La imagen no se recrea con el habla, sino con la percepción. Otra tesis de Boehm es que las imágenes tienen un sentido y un poder exclusivo de ellas. Lo importante es comprender cómo funciona la producción icónica de sentido. Pensemos que su uso se ha extendido durante la Modernidad no solo en el arte, sino en la ciencia y en la política. En los discursos políticos (por ejemplo, en los procesos electorales) la utilización de la imagen es indispensable, pero desconocemos su funcionamiento completo. De hecho, en el arte encontramos numerosas experiencias estéticas que pretenden desgranar el difuso estatus de lo icónico en sus elementos básicos: el ready made busca la imagen de una idea y reducir el objeto artístico a su valor cognitivo, o el arte minimalista que eliminaba todos los elementos plásticos superficiales hasta llegar exclusivamente a la pura percepción. Para Boehm, lo icónico descansa sobre una diferencia establecida por el ver, y además permite el ver un objeto a la luz de lo otro. Precisamente esta fenomenología de lo icónico era lo que temía la iconoclasia religiosa: la imagen de Dios en un templo solo demostraba la ausencia de Dios en ese lugar.

Según la tesis de Boehm existen razones de origen diferente para prohibir los discursos icónicos y concierne a un modo concreto de entender el concepto del lenguaje. La primera razón ya la hemos insinuado. Se trata de la primera teoría iconoclasta publicada en las Sagradas Escrituras, y que todavía en el presente son causa de conflictos y enfrentamientos.

3. No tendrás otros dioses fuera de mí. 4. No te harás escultura, ni imagen alguna de nada de lo que hay arriba en el cielo, o aquí abajo en la tierra o en el agua debajo de tierra. No te postrarás ante ellas, ni le darás culto, porque yo, el Señor tu Dios, soy un Dios celoso, que castigo la maldad de los que me aborrecen en sus hijos hasta la tercera y cuarta generación, pero soy misericordioso por mil generaciones con los que aman y guardan mis mandamientos (Éxodo 20, 4-5).

El segundo hito histórico es el veredicto expresado en la filosofía de Platón (2004, p. 676) sobre las imágenes: “A esta confesión quería yo llegar cuando dije 
que la pintura y, en general, todo arte imitativo hace sus trabajos a gran distancia de la verdad...". Para el sabio griego, con las imágenes no es posible construir nada importante, ni ciencia, ni Estado, y menos, encontrar la verdad de las cosas. Las imágenes realizan obras efímeras, sensibles y engañosas. Estas debilidades, reconoce Boehm, todavía en la filosofía contemporánea reprime conceptualmente a las imágenes a favor de su dependencia ineludible de la palabra. Finalmente, la tradición eclesiástica del cristianismo ha intervenido en dos direcciones. La posibilidad de representación del Dios reencarnado en Hombre en la imagen de Hijo Cristo dio un impulso a lo icónico en la cultura occidental. Aunque también la Iglesia siempre predicó que el auténtico cristiano escucha la palabra de Dios, y no es quien adora a las imágenes.

La influencia de estos momentos históricos sobre la cultura icónica la simplificaremos en los siguientes puntos (Dimmick, Simpson y Zeeman 2002; Besançon 2003; Boehm 2011; Kolrud y Prusac 2014; Bredekamp 2017; Contreras 2017a):

a) El recelo con las imágenes surge por su extendido deseo hacia ellas desde el siglo XIX. La concepción secular de la imagen ha fomentado su utilización masiva. Sin embargo, el primado de la palabra solo muestra que la representación por sí sola no es capaz de expresar con la precisión de los textos. Lo icónico conserva su sentido encriptado de algo que fue dicho con anterioridad. La palabra siempre antecede a la manifestación visual. La imagen se crea bajo el dictado de un texto invisible, es una escritura estructurada entre el icono y la grafía.

b) Las imágenes icónicas son siempre interesantes cuando se apropian de algo para llevar un mensaje de un lugar a otro. Para ello, las imágenes ofrecen copias del mundo. Para la imagen icónica controlar la distancia con la representación es tan importante como los problemas que supone pensar en la imposibilidad de representación. Lo prohibido, como dice Rancière (2011, p. 150), "viene entonces a inmiscuirse en esta imposibilidad, dándose como una mera consecuencia de las propiedades del objeto". Relacionarse con la mímesis implica la manera de hacer (poeisis) y la economía de los efectos (aisthesis).

c) La confianza en el lenguaje heredada de la tradición religiosa se halla bajo sospecha en la posmodernidad. El giro lingüístico descrito por Rorty (1990) demuestra que el conocimiento del mundo depende del lenguaje utilizado. Además, la multiplicación de lenguajes en la posmodernidad es consecuencia de los procesos de legitimización de sus proposiciones. Esto supone una superación del objetivismo, el positivismo y el empirismo de la ciencia moderna. La verdad se construye mediante estrategias extralingüísticas, en las que la imagen icónica ha encontrado su protagonismo. La crítica al lenguaje recupera el valor cultural de la imagen, sus derechos fundacionales, su función de mostración, las certezas intuitivas y su labor de auxilio al sentido de la palabra.

d) La función mimética de la imagen icónica es asumida como el engaño de las apariencias (Tatarkiewicz 2017). "Bien lejos, pues, de lo verdadero está el arte 
imitativo; y según parece, la razón de que lo produzca todo está en que no alcanza sino muy poco de cada cosa y en que esto poco es un mero fantasma" (Platón 2004, p. 665). Platón se interroga sobre la pintura hecha de cada cosa: el arte imita la realidad de las cosas según se da, o, por el contario, imita lo aparente según aparece. La desconfianza sobre lo que realmente muestra la imagen icónica conduce la discusión en la Modernidad hacia otros derroteros. No será la imagen, sino la voluntad creativa o productiva de ofrecer elementos significativos ("elementos encarnados", según Merleau Ponty 1970) que, de otra manera, justifique la imitación de las ideas platónicas. Para Merleau Ponty (2013), la imagen icónica no es una cuestión de copia, sino de repetición, que hace visible lo que en una realidad preexistente es invisible. Y, por tanto, cuando traemos lo invisible a la vista en una imagen es siempre bajo una intención, aunque distintas imágenes puedan representar la misma cosa o la misma persona.

Quizás lo más específico es que la mímesis de Platón es una mímesis del logos, lo cual ha puesto la imagen bajo los dictados del concepto, de la ciencia o de la lógica. De este modo, la imagen permanece subyugada a la palabra, a la narración o a la historia. Wittgenstein, los psicólogos conductistas y los teóricos del arte contemporáneo (como observa Mitchell 2017) han intentado romper con el lenguaje a este nivel, respetando otra lingüística distinta en su mecanismo interno. Existe la coacción de concebir la imagen vinculada a la palabra en términos políticos, como una cruzada de ideologías. Para Mitchell (2017), la relación entre el texto y las imágenes es consecuencia de otra relación en el mundo moderno entre la significación y la comunicación, una vinculación similar a la que establecemos entre los símbolos y el mundo o entre los signos y sus significados. Sea cual sea la unión entre el verbo y la imagen, es tan abismal como entre las palabras y las cosas. Su correlación no es natural, consiguiendo corroer el poder de las imágenes. La palabra no es lo "otro" de la imagen, es una creación artificial y arbitraria que el hombre le impone a lo visual, incorporando elementos antinaturales en su mundo como son la historia, el tiempo, la consciencia e incluso la intrusión de la mediación simbólica. Por ello, para Mitchell, la visualidad de las imágenes es un proceso de continua renovación que tiene lugar en el diálogo entre la imagen visible y el significado latente de la palabra. Esto sucede en términos de oposición análoga entre espacio y tiempo, entre naturaleza y cultura, entre lo onírico y lo real. En definitiva, nuestro mundo se construye mediante el diálogo entre construcciones verbales y representaciones visuales, entendiendo que no damos forma a la naturaleza, sino que es ella la que ya no ofrece esas formas.

\section{La guerra contra el mundo de las imágenes}

Era necesario comentar la importancia de las doctrinas que arrastran las imágenes cuando son comprendidas como elementos lingüísticos de un conocimiento productivo (como pensaba Aristóteles) que va más allá de la simple experiencia. Sin embargo, la aparición de la iconoclasia tiene diferentes tesis sobre sus orígenes; $y$, como podemos 
pensar, no es solo una oposición a ese conocimiento del mundo o a su idea, pues la imagen es resultado de la obra del hombre.

En su estudio, Freedberg (2017) traza un mapa sobre los diferentes enfoques que ha tenido este fenómeno. La censura y la iconoclasia ha tenido distintas etapas en las que se han consolidado razones para su práctica (Noble 2009; Walden 2013; Kolrud \& Prusac 2014; Verstegen 2014):

- La iconoclasia bizantina fue estudiada teniendo en cuenta como los argumentos teológicos de la época eran transformados en argumentos políticos (Herrin 2009). Los estallidos políticos contra las imágenes se repiten a lo largo de la historia. En 1566 surgieron revueltas en los Países Bajos contra el control español de las ilustraciones en libros y las imágenes en el arte. La Reforma fue ganando adeptos a medida que los gobernantes españoles imponían la doctrina de la Iglesia católica.

- Las implicaciones teóricas y estéticas también han sido causa de los conflictos con las imágenes. Existe una estética de la destrucción basada en argumentos diversos. Líderes políticos que se han opuesto a la inversión pública del Estado en concepto de adquisición de arte, porque pensaban que era más urgente aliviar el estado de pobreza del país. Otra oposición a la exhibición de la obra visual radica en su ubicación pública. La cuestión es quién decide donde debe colocarse esa obra de arte y qué debe mostrarse en el espacio público. Es un ejemplo contemporáneo la obra "My bed" (1998) de Tracey Emin, en la que vemos su cama en un entorno decadente rodeado de basura y condones usados.

- La crisis ideológica de la segunda mitad del siglo XX y la crisis de los metarrelatos de la Posmodernidad (Lyotard 2012) ha ocasionado el clima de activismo político de las últimas décadas. Los movimientos obreros de final siglo XIX parecen recuperarse en los últimos movimientos sociales (p. e. el $15 \mathrm{M}$ en España). Estos emergentes activismos de los movimientos sociales practican la iconoclasia como una táctica política en sus reivindicaciones. Los reflejos de este activismo político han alcanzado al arte contemporáneo. En la obra del artista Santiago Sierra es constatable su utilización en la crítica severa de la iconografía mediática de la frontera. Sierra arremete contra el abuso de las imágenes mediáticas que condicionan la opinión pública respecto a la política oficial migratoria en España. La obra titulada "Palabra tapada" (2003) es un gesto iconoclasta que consiste en tapar con plásticos y cintas adhesivas el rótulo "España" sobre la puerta del Pabellón Español de la Bienal de Venecia en junio de 2003.

- La iconoclasia no depende solo de factores políticos, sino que inciden otros de carácter psicológicos y sensoriales. Para Freedberg (2017), incluso cuando tratamos con imágenes abstractas, se produce una reacción fenomenológica entre los cuerpos representados y los cuerpos de los espectadores. Si bien las investigaciones más extendidas estaban dirigidas a la encarnación, el 
deseo y el impulso de mirar las imágenes (es el caso de la idea del deseo y el impulso en la obra del artista Salvador Dalí o en el estudio cultural sobre el simulacro de Baudrillard 2005), para Freedberg la iconoclasia depende de respuestas corporales y de motivos psicológicos mucho más complejos y difíciles de comprender.

- Otra vía de investigación de la iconoclasia es la relación con la misma historia del arte. En esta dirección apuntan los trabajos de Hans Belting (2009) y de Robin Cormack (Jeffreys, Haldon \& Cormack 2008). Estos estudios establecen una relación causal entre la manifestación de la iconoclasia y los acontecimientos históricos de un momento y un lugar concreto. Realmente son investigaciones también orientadas a los efectos originados por la idolatría en las circunstancias históricas. La idolatría considera sus imágenes poderosas y con vida propia. Las imágenes políticas como las imágenes sagradas de los idólatras adquieren la fuerza en su creencia. Por ello es que los actos de iconoclasia no son solo "una estructura de creencias, sino una estructura de creencias sobre las creencias de otras personas" (Mitchell 2017, p. 44).

- La iconoclasia sobre el arte contemporáneo es también un fenómeno de reciente aparición. Las obras de arte son objetos de ataques, mutilaciones o destrucciones, a menudo por razones políticas, pero también por el deseo de castigar al autor y a la obra en sí. Por razones antropológicas, concretamente por la actitud emocional del espectador, las obras de arte sufren las agresiones iconoclastas. Freeland nos expone el ejemplo del "Cristo del Pis" (1987) de Andrés Serrano, y los numerosos intentos de destrucción por espectadores ofendidos. La obra consiste en una fotografía de un Cristo introducido en un tarro de orina. Además, a estas acciones debemos sumar que la destrucción de la imagen es adoptada ahora como una estrategia de la creatividad artística. "Dejando caer una urna de la dinastía Han" (1995) es una acción del artista Ai Wei Wei en la que rompe una antigua urna fechada entre los años 206 a.C. a 220 d.C.

- Las iconoclasias sobre las imágenes mediáticas tienen otro ejemplo en la censura de las imágenes de los acontecimientos de Irak en 2003. Demuestra, en palabras de Freedberg (2017), que la iconoclasia es un fenómeno que no se da solo en otros lugares, sino que se presenta en la cultura occidental actual. Las iconoclasias de las artes mediáticas surgen de su acción colonizadora y descolonizadora, amplificada por el efecto de globalización de la reproducción digital.

Las acciones de la iconoclasia comienzan por la destrucción de las imágenes de los libros, la mutilación de obras de artes, las tachaduras de la censura, las rectificaciones o las sustituciones de elementos integrantes de la obra visual y la desaparición o la eliminación de esas imágenes. Ya desde tiempos pasados, los iconoclastas actúan sobre las imágenes de los gobernantes odiados, las representaciones de las figuras políticas que proclaman doctrinas inadmisibles o luchan contra las doctrinas contrarias a sus ideas. Han desaparecido las obras visuales eróticas, sensuales o libidinosas, así como 
aquellas consideradas de mal gusto o, simplemente, feas, desagradables o impropias para el espacio público (Eco 2015; Freeland 2010; Tatarkiewicz 2017; Henderson 2018).

\section{La iconoclasia política en la posmodernidad}

Nos referimos a una iconoclasia política cuando el origen de los ataques a las imágenes no son hechos espontáneos, particulares y aislados, sino que detrás de estas acciones existe una organización. El precedente político más importante fue la iconoclasia bizantina. Cuando era necesario robustecer el poder imperial se cruzaron otros factores como la negación de las imágenes por núcleos árabes de pensamiento y el debate sobre la cristiandad. Las disputas cristocéntricas se hicieron rápidamente debates políticos. La iconoclasia política pondrá en funcionamiento sus argumentos a través de otras tácticas que oculten las superficiales razones teológicas. Detrás de estas razones se esconderán otros motivos más habituales, como los políticos o los psicológicos (sentimentales o emocionales). No obstante, todos tenían algo en común que alcanzaba la opinión pública y que consistía en la defensa de la verdad. Desde las preocupaciones griegas, la verdad y la invención del arte han guardado una estrecha relación (Tatarkiewicz 2017). Durante el período clásico en Grecia coexistieron dos teorías sobre esta cuestión. La primera sostenía que el arte visual y la poesía expresan la verdad, siendo su defensor Sócrates; la segunda teoría, todo lo contrario, que producen ilusiones, falsedades conscientes o mentiras. La poesía era denunciada por sus ficciones que engañaban. Esta teoría fue respaldada por Gorgias y sus discípulos. La concepción de Platón fue la existencia de dos verdades: objetiva y subjetiva. Para el filósofo, la verdad solo es posible representando fielmente las configuraciones de las cosas. Esta verdad objetiva era considerada individual, universal e ideal. La tesis de Platón se ha mantenido a lo largo de la historia. Durante el siglo XVII la literatura clásica valoraba la verdad de una obra a partir de los principios universales con los que las cosas se representaban de acuerdo a su ordenación. También los lógicos pensaban del mismo modo: Adaequatio rei et intellectus. Desde el Renacimiento hasta las Edad Moderna, la intencionalidad del arte tampoco supuso un problema para enjuiciar, que el arte aproxima al hombre hacia la verdad a través de la ficción. El arte utiliza la definición de verdad para a) la pureza de estilo de una obra; b) la autenticidad de la obra (la originalidad que emana de su autor; c) la solidez de la finalidad y los medios de la obra de arte; y finalmente, d) la sinceridad con la que se expresa la obra. Según Tatarkiewicz, esta multiplicidad podría reducirse a tres significados: "conformidad con la realidad, conformidad con la idea del creador y conformidad interna de la obra" (2017, p. 350). La idea romántica de Hegel sobre la vocación del arte en la búsqueda de la verdad también nos ha alcanzado en el presente. De ello, ya somos conscientes frente al valor estético de las campañas políticas; el mismo Walter Benjamin (1992) ya reconocía el proceso de estetización de la política frente a los acontecimientos políticos de Alemania o de Rusia a mediados del siglo $\mathrm{XX}$.

La iconoclasia teme precisamente la sutileza del arte para generar confianza en sus imágenes. Partiendo de la generalización más extensa, sintetizamos los recursos estratégicos del arte para convencer sobre las ideas auxiliadas por su visualidad: 
- El activismo visual ofensivo. El hombre ofende a la imagen. Estas imágenes están inmediatamente vinculadas al objeto o a la persona que representa. Cuando el hombre ataca a la imagen lo hace también a lo que simboliza. Tenemos ejemplos de rostros de esculturas mutilados en la antigua Mesopotamia y en Egipto. Estas acciones han continuado hasta el presente. Es un ejemplo el derribo de las estatuas de Sadam Husein tras la guerra de Irak en la primavera del 2003. Otro comportamiento de una imagen ofensiva (Mitchell 2017), son las guerras culturales. En estas ocasiones, la imagen combate una tradición o una costumbre local con un espíritu transformador de la realidad social.

- La reencarnación. Las imágenes tienen vida propia y son tratadas como si fuesen la misma persona que representan. La imagen experimenta lo mismo que la persona representada (deseos, sentimientos, emociones, intenciones). Las obras visuales son consideradas seres vivos sensibles que sufren, gozan y son socialmente afines. Es un ejemplo cualquier icono sagrado objeto de adoración extrema a los que se les atribuye propiedades mágicas o milagrosas. Para algunos creyentes, solo Dios tiene el poder de infundir vida a las imágenes creadas, sobre todo, en aquellas que representan a seres vivos. Los antecedentes más importantes de estas hostilidades están en la Reforma protestante entre luteranos y calvinos, cuando pretendían eliminar los gastos de la idolatría para salvar a la humanidad de la pobreza.

- El miedo a los instintos sexuales enaltecidos por la imagen de la carne o los movimientos sensuales del cuerpo se esconde detrás de la censura. La carnalidad, la sexualidad o el erotismo en las imágenes generaban en los hombres impulsos temidos que conducen al caos e impiden el desarrollo civilizatorio del hombre. La misoginia de Schopenhauer defendió esta tesis. En numerosas ocasiones, las esculturas han sido desfiguradas por exhibir la sensualidad o la virilidad del cuerpo humano. La posibilidad de un efecto físico sobre el deseo del público era un motivo para estas amputaciones que arrastraban sentimientos de vergüenza y hostilidad a la exposición de la sexualidad humana.

- La crisis de las instituciones y la desconfianza frente a su ideología y a su estructura organizativa ha movilizado a los humanos alrededor de acciones iconoclastas. Durante la Revolución francesa, los principales gestos iconoclastas se acometieron contras todas las imágenes de una autoridad que representara al Antiguo Régimen y a todo aquello que provenía de la Edad Media (retratos reales, símbolos de la nobleza, autoridades eclesiásticas, órdenes caballerescas, etc.). Lo mismo sucedió durante la Revolución rusa, pero con las imágenes de los zares y sus familias; y tras la caída de la URSS en 1989, también las esculturas de Lenin y Marx fueron derribadas. En esta crisis de las instituciones, aparecen también ejemplos contra el colonialismo 
europeo en otros continentes o la iconoclasia frente a los símbolos del neocolonialismo cultural resultado de la globalización y de la digitalización.

Las patologías de la iconoclasia pueden combinar los motivos (erotismo, religión, creencia, política, ideología) que organizan a la comunidad alrededor de la destrucción o la amputación de las imágenes. Los comportamientos más comunes de la mutilación iconoclasta afectan al rostro de las imágenes. Concretamente, a los ojos. La destrucción de los ojos de las imágenes (pinturas, fotografías o esculturas) es un modo de evitar que la figura representada pueda mirarnos, pero también que podamos ver su humanidad. Quitar los ojos a un rostro es eliminar de la representación una cualidad importante que permite exponer su vitalidad y la expresión que le dota de humanismo. Otro elemento significativo del rostro es la boca por razones semejantes. Las amputaciones de otras partes del cuerpo tienen que ver con la incapacitación de ejercer las acciones que a la obra visual se le atribuía: si le eliminan los brazos a una escultura política, se le impide la posibilidad de expresar los sentimientos paternalistas de un abrazo a su pueblo amado. Además, siempre hay algo más: "La voluntad de destruir una obra a menudo indica el empeño de negar que, en cierto modo, la imagen es algo viviente. Precisamente, es esta capacidad la que la convierte en algo peligroso, en objeto que precisa ser eliminado, mutilado y destruido" (Freedberg 2017, p. 58).

La iconoclasia tiene una fase inicial de censura política, pues acomete contra la dignidad y el honor de la persona. Una vez más, la atracción o la repulsión que causa una imagen se percibe como algo alarmante, ya que se entiende que la acción recae sobre el propio cuerpo del representado. El modo más común de atentar contra la nobleza de las personas es con el uso político de la sátira. Las imágenes satíricas deben ser controladas, pues su ataque proviene no solo de la información que transmiten, sino de la propia deformación que se produce en la imagen modificando el rostro, el cuerpo o la acción. Un ejemplo contemporáneo son los memes políticos que se envían a través de las redes sociales. Con la censura iconoclasta se pretende también abordar sensibilidades estéticas ofreciendo aspectos de las personas que son degradantes, o sencillamente, increpar el contenido visual. Básicamente, los creadores sobrepasan las normas sociales mediante variaciones sobre la imagen o incrementando los significados licenciosos para afectar al público. Debemos comprender que, en la cultura occidental basada en semejanzas semánticas, las imágenes también se disciernen como signos legibles y dotados de un significado. Además, no podemos obviar que la estética de la destrucción aparece también tras una actitud antiespectáculo (siendo la espectacularidad tan importante en la política, como ya mostraron los situacionistas franceses) que procede "del temor iconoclasta a la idolatría que se encuentra en los sectores ascéticos de las tres grandes religiones occidentales y de la idea de que lo real no puede representarse" (Jay 2007, p. 327). Esta actitud también tiene relación con la crítica académica del arte de masas. Carroll nos recuerda que los estudios culturales consideran que las obras de arte de masa "tienen consecuencias causales previsibles, en la conducta moral de los espectadores, oyentes, lectores. La exposición al arte de masas influye o forma la conducta" (2002, p. 251). Además de la significación y de la simbolización, la iconoclasia temía que la visualización de la violencia generará violencia. Es decir, que la valoración moral de 
la obra de arte provocará reacciones políticas y revueltas sociales. Las obras visuales se pueden interpretar como máximas morales (o inmorales). Para Carroll, la obra de arte de masas no solo predica una moralidad, sino que la promueve, estimulando su adopción mediante la seducción del público.

Las transgresiones políticas de las imágenes suscitan prácticas morales que activan los comportamientos iconoclastas desde un amplio contexto:

- Una imagen es agresora dependiendo de un contexto social concreto. Estos contextos cambian temporalmente, como resultado de un debate público acerca de la imagen. Su agresividad disminuye después del primer impacto sobre la opinión pública, incluso llegando a ganar el afecto de la colectividad. El carácter agresivo depende de la interacción social entre una cuestión específica y la comunidad, pudiendo cualquiera de los dos factores haber experimentado cambios en el tiempo.

- La iconoclasia es un fenómeno comunicativo, luego es posible que la imagen pueda agredir al objeto representado o al observador. La reacción iconoclasta proviene de la imagen que desacraliza algo sagrado, devalúa el valor del objeto representado o hace valioso algo despreciable. Estas imágenes pueden agredir por su forma de presentar ese algo o por su asociación con otra cosa execrable.

- Si la imagen es objeto de la iconoclasia, la comunidad se organiza alrededor de una decisión judicial, política o una imposición autocrática.

- En otras ocasiones, el gesto iconoclasta surge de la ofensa a la misma imagen. Se trata de perseguir la obra visual hasta su extinción, y otras veces, solo de una desaparición parcial mediante una manipulación visual que desfigura o mutila una parte. No busca la erradicación de la obra, sino conservarla, renovarla y volverla a armar visualmente para que de nuevo cumpla con su función ofensiva. Según Mitchell, la caricatura sería un ejemplo de este estilo de iconoclasia: "Para resumir, entonces, parece que hay tres estrategias básicas de iconoclasia: aniquilación, desfiguración y ocultamiento" (Mitchell 2017, p. 172). Con la caricatura lo que se pretende es ocultar la auténtica imagen del objeto representado a la mirada.

Un sentimiento iconoclasta más reciente es el rechazo a la deformación del sentido histórico de los monumentos. En la larga historia de las esfinges, los monumentos conmemorativos y las obras artísticas rememorativas que son vandalizadas, derribadas y resucitadas, y vueltas a aparecer, nos encontramos los monumentos repudiados por la iconoclasia. Son aquellos monumentos que ya no enriquecen la memoria popular y en los que apenas queda su importancia histórica. El monumento berlinés erigido por los Nachgeborenen conmemora las víctimas de los crímenes nazis contra la humanidad que dieron origen a la convención de 1948 sobre el genocidio judío e impulsaron el discurso transnacional sobre los derechos humanos; el local del World Trade Center de New York es ahora un monumento que recuerda los atentados terroristas del 11 de 
septiembre del 2001. Huyssen (2015) es crítico respecto a estas imágenes: ahora solo sirven como grandes centros de atracción turística. El miedo iconoclasta proviene de la ubicuidad del discurso de la memoria en el público o del discurso ocioso de los medios de comunicación. Según Huyssen es muy probable que la amenaza sobre el conocimiento histórico objetivo elimine las fronteras entre un pasado inventado y el presente vivido. Y es que la industria de la cultura del consumo pone al servicio de la lógica del mercado la nostalgia, el pasado y la necesidad creciente de la historicidad en un mundo de obsolescencia programada (Huyssen 2015, p. 139).

El aumento de desconfianza hacia las representaciones en la cultura digital ha perfilado otros modos más sutiles de censura. Mediante la utilización de algoritmos específicos, la detección de imágenes permite la prohibición o la marginación visual. El ordenador reconoce la pornografía u otras imágenes censuradas por la cultura con fórmulas taxonómicas complejas. Steyerl (2018) explica que esta detección o la vigilancia de las imágenes se basan en programas autodidactas de la computación cognitiva.

Si bien todavía existen dificultades técnicas considerables, este intento representa un nuevo nivel de formalización; un nuevo orden de imágenes, una gramática de las imágenes, un sistema algorítmico de la sexualidad, la vigilancia, la productividad, la reputación y la computación que se vincula con la gramaticalización de las relaciones sociales por parte de las corporaciones y los gobiernos (Steyerl 2018, p. 55).

Desde su sentido de prohibición, la cultura digital ha satisfecho una demanda antigua del arte revolucionario que conectaba con otra manifestación iconoclasta en contra del fetichismo del arte. Para este arte del proletariado, el artista debía emplear necesariamente los medios (la máquina, la imprenta, la electricidad, la radio, la iluminación, etc.) en colaboración con la construcción de la sociedad, evitando el fetichismo de los instrumentos estéticos (Arvátov 2018). Las tecnologías digitales han acrecentado la producción visual, logrando que en el arte contemporáneo sean visible los imaginarios populares y marginales de la cultura obrera. Durante los años sesenta, el arte pop elevó a la categoría de arte los objetos que producía la industria como un modo de visibilidad de la cultura del daily life (Danto 2012; Zurrón 2006). En el mundo moderno, la sublimación es alquimia del alma que genera iconoclasia en el arte. La sublimación, como la describe Didi-Huberman (2012), hace de la imagen un síntoma de enfermedad. Las imágenes pueden causar sensaciones inquietantes e incluso desagradables a la vista. La fuerza de su extrañeza nace de su plano de inmanencia (gestual, somático y anímico) que provoca una actitud pasional, algo que llama Didi-Huberman (2012, p. 48), "síntoma". La sublimación (Sublimierung) ofrece una especial atención a la pulsión de la mirada (Schautrieb). La mirada puede bloquearse frente a una inhibición neurótica. Las imágenes actúan de consuelo frente al dolor cuando subliman los hechos inhibidores en la conducta humana mediante los ornatos de una recreación visual. Estas pulsiones emergen en la idolatría y en el fetichismo. Por este motivo, Marx temía la pulsión del capitalismo introduciendo el fetichismo de la mercancía, y en contraposición, mantenía una postura iconoclasta frente a la racionalización elitista de la estética o a la mixtificación de los objetos de culto (Durán Medraño 2009). El desafío marxista está 
actualmente vigente. Las cualidades de pureza, singularidad y el sentido atemporal del arte le hace indestructible en el devenir histórico. El sentimiento iconoclasta se extiende sobre la idolatría mediática de las imágenes publicitarias o del discurso político de los medios de comunicación.

\section{Conclusiones}

De lo expuesto podemos extraer las siguientes conclusiones: a) La iconoclasia es un síntoma cultural de repulsión visual que surge por las historias formadas de la unión entre las palabras y las imágenes. Alrededor de esta sintomatología cultural, el poder de los Estados y las instituciones ha organizado a las comunidades para la destrucción o para la censura de la obra visual. La primera función política de la iconoclasia sería pues el control de los impulsos de la colectividad y sus correspondientes áreas de producción visual, por ejemplo, el espacio de la imagen frente al texto en la historia de la comunidad. La iconoclasia articula su acción en contra de la fecundidad de la imagen como documento para instruir el proceso de la historia. De este modo, la iconoclasia recompone las fuerzas de lo político por descomposición y declaración ordenada de la historia. La iconoclasia actúa de forma eficaz en una toma de posición crítica que desarma el relato de las imágenes y su disposición de las cosas en el tiempo; b) Los iconoclastas destruyen ídolos, que son otro tipo de imagen. Apartando las disquisiciones teológicas, los ídolos representan a los otros frente a los iconos que recrean nuestra propia cultura desde la repetición. Estas imágenes no serían objeto de neutralización iconoclasta si carecieran del valor de la memoria y del uso restrictivo del tiempo, situándose su influencia sobre el espacio público en un presente sincrónico. El iconoclasta termina con el conflicto de la autoridad del ídolo, eliminando con su agresión el significante de la forma, al que considera responsable de la relación de la mirada con la ideología desestabilizadora; c) La iconoclasia condena las ficciones idólatras basadas en la articulación simbólica del icono. Los simulacros ópticos provocados por la mimética especular provocan transitorios goces de ilusión. Lo imaginario colectivo perece frente a la falsedad de las copias hipnotizadoras o de las seductoras ficciones inmanentistas. Por lo que en toda acción iconoclasta hay también un reconocimiento del valor psicológico de la imagen icónica en el establecimiento de un orden comunitario y social; y d) la iconoclasia impone una violencia inspirada en la teología política. La adoración de las imágenes ha impuesto un régimen escópico determinado que discrimina entre la imagen y lo visual. La visualidad es precisamente el índice del estado de las cosas. Aquí distinguimos un estado que exige la interpretación personal de las imágenes. El observador busca con la mirada lo que hay detrás de lo visual: adorar a las imágenes era la consecuencia del respeto riguroso a las representaciones. En la posmodernidad, el estado de las imágenes es resultado de un nuevo comportamiento basado en la admiración a los efectos técnicos que generan falsos artificios. Los impulsos irracionales (emocionales, sentimentales) son más importantes que las verdades racionales que nos quieren comunicar las imágenes. La iconoclasia surge no de las creencias que abre lo visual al espectador, sino de su adicción por el goce vacío que sobre el observador provoca. 


\section{Referencias bibliográficas}

AA. VV. (2010), La Biblia. Madrid: Ediciones SM y Editorial PPC.

Arvátov, Borís (2018), Arte y producción. Madrid: Ediciones Asimétricas.

Baudrillard, Jean (2005), Cultura y simulacro. Barcelona: Kairós.

Belting, Hans (2009), Imagen y culto: una historia de la imagen anterior a la edad del arte. Madrid: Akal.

(2012), Florencia y Bagdad. Una historia de la mirada entre Oriente y Occidente. Madrid: Akal.

Benjamin, Walter (1992), Sobre arte, técnica, linguagem e política. Lisboa: Relógio D'Agua Editores.

Besançon, Alain (2003), La imagen prohibida: una historia intelectual de la iconoclasia. Madrid: Siruela

Boehm, Gottfried. (2011), “Más allá del lenguaje? Apuntes sobre la lógica de las imágenes”, en A. M. García Varas, ed., Filosofía de la imagen. Salamanca: Ediciones Universidad de Salamanca; pp. 87-106.

Bredekamp, Horst (2017), Teoría del acto icónico. Madrid: Akal.

Carroll, Noël (2002), Una filosofía del arte de masas. Madrid: La Balsa de Medusa.

Contreras, Fernando R. (2017a), "Estudio sobre los planteamientos teóricos y metodológicos de los Estudios Visuales", Arte, Individuo y Sociedad 29 (3): 483-499.

(2017b), "Ichtus o Ichthys", en M. Ramírez, M. y M.A. Martínez, eds., 50 imágenes para la Historia de la Comunicación. Imago Mundi. Valencia: Tirant Humanidades; pp. 84-93.

Danto, Arthur C. (2012), Después del fin del arte: el arte contemporáneo y el linde de la historia. Barcelona: Paidós.

Davidson, Clifford, Nichols, Ann Eljenholm, (eds.), (1989), Iconoclasm vs. art and drama. Kalamazoo, Mich.: Medieval Institute Publications, Western Michigan University.

Didi-Huberman, Georges (2012), Arde la imagen. Oaxaca: Serieve.

Dimmick, Jeremy, James Simpson, Nicolette Zeeman (eds.), (2002), Images, idolatry, and iconoclasm in late Medieval England: textuality and the visual image. Oxford: Oxford University Press.

Durán Medraño, José María (2009), Iconoclasia, historia del arte y lucha de clases: sobre las relaciones entre economía, cultura e ideología. Madrid: Trama Editorial.

Eco, Umberto (2015), Historia de la fealdad. Barcelona: Lumen.

Freedberg, David (2017), Iconoclasia: historia y psicología de la violencia contra las imágenes. Victoria-Gasteiz: Sans Soeil.

Freeland, Cynthia. (2010), Pero ¿esto es arte?: una introducción a la teoría del arte. Madrid: Cátedra. 
Gamboni, Darío (2014), La destrucción del arte: iconoclasia y vandalismo desde la revolución francesa. Madrid: Cátedra.

Henderson, Gretchen (2018), Fealdad: una historia cultural. Madrid: Turner.

Herrin, Judith (2009), Bizancio: el imperio que hizo posible la Europa moderna. Barcelona: Debate.

Husserl, Edmund (2011), La idea de la fenomenología. Barcelona: Herder Editorial.

Huyssen, Andreas (2015), Culturas do pasado-presente. Modernismos, artes visuais, política da memoria. Rio de Janeiro: Contraponto.

Jay, Martin (2007), Ojos abatidos. La denigración de la visión en el pensamiento francés del siglo XX. Madrid: Akal.

Jeffreys, Elizabeth, John Haldon \& Robin Cormack (2008), The Oxford handbook of Byzantine studies. Oxford: Oxford University Press.

Jones, Beth \& Jeffrey Barbeau (2016), The image of God in an image driven age: explorations in theological anthropology. Downers Grove, Illinois: IVP Academic.

Kolrud, Kristine, Marina Prusac (eds.), (2014), Iconoclasm from antiquity to modernity. Burlington, VT: Ashgate Publishing Company.

Lipovetsky, Gilles y Jean Serroy (2015), La estetización del mundo: vivir en la época del capitalismo artístico. Barcelona: Anagrama.

Lyotard, J. (2012), La condición postmoderna: informe sobre el saber. Madrid: Cátedra.

Matusitz, Jean-Françoise (2015), Symbolism in terrorism: motivation, communication, and behavior. Lanham, Maryland: Rowman \& Littlefield.

Merleau Ponty, Maurice (2013), El ojo y el espíritu. Madrid: Trotta.

(1970), Lo visible y lo invisible. Barcelona: Seix Barral.

Michalski, Stefan (1993), The Reformation and the visual arts the Protestant image question in Western and Eastern Europe. London: Routledge.

Mitchell, William (2017), ¿Qué quieren las imágenes? Vitoria-Gazteiz: Sans Soleil.

Morgan, David (2005), The Sacred Gaze Religious Visual Culture in Theory and Practice. Berkeley: University of California Press.

Noble, Thomas (2009), Images, iconoclasm, and the Carolingians. Philadelphia: University of Pennsylvania Press.

Otero, Carlos, Gottfried Boehm, Boris Groys, Hans Belting, Jan Assmann, MarieJosé Mondzain, Thomas Hobbes (2012), Iconoclastia: la ambivalencia de la mirada. Madrid: La Oficina.

Peffer, John (2009), Art and the end of apartheid. Minneapolis: University of Minnesota Press.

Platón (2004), La República. Santa Fe: El Cid Editor.

Pochat, Götz (2008), Historia de la estética y la teoría del arte. De la Antigüedad al siglo XIX. Madrid: Akal.

Rancière, Jacques (2011), O destino das imagens. Lisboa: Orfeu Negro. 
Rorty, Richard (1990), El giro lingüístico: dificultades metafilosóficas de la filosofía lingüística. Barcelona: Paidós.

Spraggon, Julie (2003), Puritan iconoclasm during the English Civil War. Woodbridge, Suffolk, UK; Rochester, NY: Boydell Pres.

Steyerl, Hito (2018), Arte Duty Free. El arte en la era de la guerra civil planetaria. Buenos Aires: Caja Negra.

Stubblefield, Thomas (2014), 9/11 and the visual culture of disaster. Bloomington, Indiana: Indiana University Press.

Tatarkiewicz, Wladyslaw (2017), Historia de las seis ideas. Arte, belleza, forma, creatividad, mímesis, experiencia, estética. Madrid: Tecnos.

Verstegen, Ian (2014), Cognitive iconology: when and how psychology explains images. Amsterdam, Netherlands: Editions Rodopi.

Walden, Jennifer (2013), Art and destruction. Newcastle upon Tyne, England: Cambridge Scholars Publishing.

Waldenfelds, Bernhard (2011), "Espejo, huella y mirada. Sobre la génesis de la imagen”, en A. M. García Varas, ed., Filosofía de la imagen. Salamanca: Ediciones Universidad de Salamanca; pp. 155-178.

Zurrón, Albert (2006), El mito de la fealdad. Santa Fe, Argentina: El Cid Editor. 